International Journal of Social Science And Human Research

ISSN(print): 2644-0679, ISSN(online): 2644-0695

Volume 04 Issue 05 May 2021

DOI: 10.47191/ijsshr/v4-i5-03, Impact factor-5.586

Page No : 879-884

\title{
Impact of Covid-19 Lockdown on Socio-Economic Conditions of Semi-Skilled Returnee Migrant Workers of Bangladesh
}

\author{
Isret Jahan', Fahmedur Rahman Himel ${ }^{2}$, Dr. Md Nurul Amin ${ }^{3}$ \\ ${ }^{1}$ Master of Development Studies Bangladesh University of Professionals, Mirpur Cantonment, Dhaka 1216, Bangladesh \\ ${ }^{2}$ BSS in Disaster and Human Security Management, Bangladesh University of Professionals, Mirpur Cantonment, Dhaka 1216, \\ Bangladesh \\ ${ }^{3}$ Associate Professor, Department of Public Administration, Jahangirnagar University, Savar, Dhaka 1342, Bangladesh
}

\begin{abstract}
The study explores immediate impact of COVID-19 lockdown on socio-economic conditions of the returnee migrants in Bangladesh. Using digital platform the study collects primary data through survey on returnee migrants of Bangladesh, and it follows descriptive mode of analysis. The study finds that the majority of the returnee migrant's family members are dependent on the remittance. The workers return home because of the shutting down of their income sources due to a prolong period of lockdown. After returning home many returnee migrants get harassed by their neighbour and have problems in receiving healthcare services and maintain quarantine. Most of the returnee workers spend their savings to survive during lockdown. After four month of lockdown, the returnee migrants who think about remigration and re-join their previous job, they face several challenges like financial problem, visa renewing, job contract renewing, unavailability of plane tickets, and getting corona negative certificate.
\end{abstract}

KEYWORDS: Returnee migrants, semi-skilled workers, COVID-19 lockdown, migrant workers, socio-economic impact, remigration, Bangladesh

\section{INTRODUCTION}

Bangladesh plays an emerging role in exporting human resources around the world that helps to improve and enrich the socioeconomic conditions of the poor and middle-class communities in home country. Hence, overseas employments are not only a job opportunity for the workers but also a source of family income, economic and social development in Bangladesh (UNDP 2020). Every year thousands of people from Bangladesh travel overseas to the countries of the Global South, GCC, Middle East and the South East (Karim et al 2020). Among them, young persons from the rural areas of Bangladesh are more likely to migrate for overseas employment in these countries. Most of them travel on a contract of work typically between three to ten years as unskilled or semi-skilled workers (Sorkar, 2020). They have to return to Bangladesh for renewing the contract to re-join the work or search works in other countries. Migrant workers are always contributing positively to the socio-economic development of Bangladesh (UNDP 2020; BMET 2020; Karim et al 2020; Sorkar, 2020). However, due to the outbreak of the Covid-19 pandemic, the worldwide labour market directly and indirectly affects the life and livelihood of the semi-skilled and unskilled migrant workers from Bangladesh (UNDP 2020; Sorkar, 2020).

The semi-skilled and unskilled Bangladeshi migrant workers generally get occupied in small and medium businesses like 'tailors and masons; housemaids and agricultural workers, hotel workers, and such basic laborers as cleaners, cart loaders, and cotton pickers' (Abdullah, 2014). And it is known to all that due to the Covid-19 pandemic thousands of work sources get closed and millions of people get unemployed around the world. Similarly during Covid-19 pandemic, a significant number of Bangladeshi migrant workers have returned from the host countries because of the loss and/or forced shut down of their jobs and/or businesses (Karim, 2020, Abrar 2020). As a result numerous socio-economic crises arise such as shelter for quarantine of the returnee migrants, deficiency in health services, unemployment, food insecurity, and, financial support for livelihood of the returnee migrants (Ala Uddin 2020; UNDP 2020)

There are many works on socio-economic status and conditions of migrant workers in previous years where some studies are aligned with remittance and some are focused on voluntary homecomings for social and family developments, their life styles, and social safeties and policies (Rahman, 2017; Sarker, 2018; Siddique, 2012; Siddiqui, 2005). Considering the Covid-19 pandemic circumstance a few studies were conducted on the socio-economic status of returnee migrants workers. Specially, after four months of the lockdown, it is expected that this study will bring a different scenario from the previous studies where the concerned bodies 
and policymakers can get an idea of what are the most urgent supports of the returnee migrants required. Moreover, the study will help the researchers and practitioners to get concrete view on socio-economic status of returnee migrants in taking migration related decisions in time so pandemic or crisis situation.

\section{OBJECTIVES AND STUDY METHOD}

This study is intended to explore the immediate impact of COVID-19 lockdown on socio-economic conditions of the semi-skilled returnee migrant workers in Bangladesh. Based on this broad objective, first, the study tries to understand the socio-economic conditions of the returnee workers. After that, it investigates the reasons behind returning home in time of pandemic. Then it explores the immediate socio-economic impact of returning home country. Finally, it discovers the challenges of returnee workers with regard to the remigration and re-joining their previous job.

The study collects primary data from Bangladeshi semi-skilled returnee migrant workers through 'Voluntary Response Sampling' techniques. The semi-skilled works are referred as "the workers have moderately broad knowledge and the practical and solve regular problems by using simple techniques under supervision but autonomy to a certain degree (ILO, 2014)". A total of twenty six respondents have participated voluntarily in the survey. The semi-structured questionnaire was developed and designed in three parts. In the first part, the questions are designed to collect information about the respondent's general background, family information, and educational qualifications.

In the second section, the questions are designed to collect information about returnee migrants' socio-economic conditions in home country as a result of lockdown, and the final part of the questionnaire design to collect information about the respondent's future plan after four months of lockdown. This study uses descriptive statistics for its analysis. Using MS Excel software the collected data have been presented through table, pie chart, and bar graphs.

\section{FINDINGS OF THE SURVEY}

\section{General background of the returnee migrant workers}

The analysis general background of the returnee migrants shows that out of 26 respondents, 22 (84.6\%) are male and $4(15.4 \%)$ are female workers. On the other hand, the age distribution of the returnee migrant workers shows that 18 percent respondents belong to the age group between $20-24$ years where $75 \%$ are male and $25 \%$ are female worker. The highest proportion (33\%) among the sample belongs to the age group between 25-29 years, and all of them are male. The 23\% belongs to 30-34 years age group were $71 \%$ are male and $21 \%$ are female respondents. Again, $18 \%$ of the returnee migrant workers are at 35-39 years age group, and only 4 percent of the respondents belong to 40-44 and 45-49 years age groups where all respondents are male.

The analysis of formal educational background shows that only $4 \%$ of the respondents completed the primary school education, $27 \%$ workers have passed SSC (Secondary School Certificate) examination, 34\% have passed HSC (Higher Secondary Certificate) examination, $31 \%$ have completed graduation and only $4 \%$ have completed master degree.

In case of marital status of the respondents, $46 \%$ of returnee workers are married and $46 \%$ are unmarried. Another $4 \%$ of respondents are divorced and remaining $4 \%$ are widowed. Figure- 1 presents the working experiences of the returnee migrants. It shows that among the Bangladeshi returnee migrant workers, $39 \%$ have working experience of 1-5 years, whereas $38 \%$ of them have $5-10$ years, $1 \%$ has $10-15$ years, and $8 \%$ have $15-20$ years of working experience.

\section{Figure-1 Working experiences of the returnee migrants}

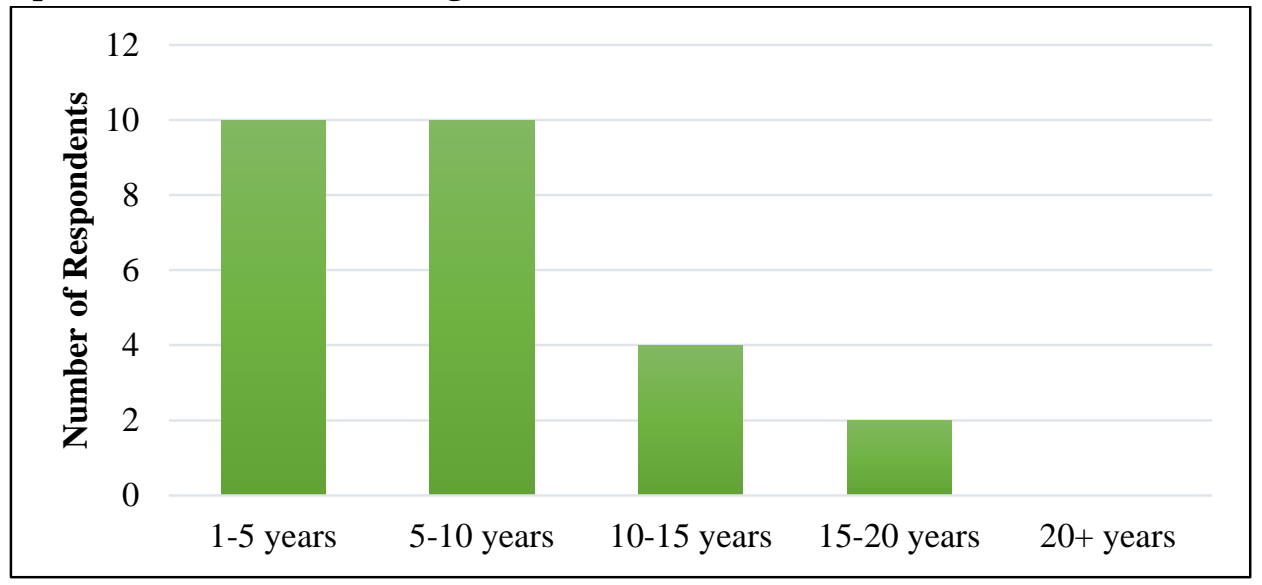

Source: Online voluntary response survey, October 2020 
The analysis of total household members of returnee workers show that the minimum and the maximum number of household members are 2 and 8 members, respectively and the average household member is 3.71. The largest proportion of the respondents (31\%) have 6 household members. $23 \%$ of the responders have 5 household members, $19 \%$ of the responders have 7 household members, $14 \%$ of the responders have 4 household members and household members with 2, 3 and 8 people have $4 \%$ respectively among the respondents.

The dependency of the family members of returnee migrant workers on remittance presents in Figure-2. It shows that the family members of $73.10 \%$ returnee migrants are dependent on the remittance while only $26.90 \%$ response that their family members are not fully dependent on their income.

Figure-2: Dependency of the family members on remittance

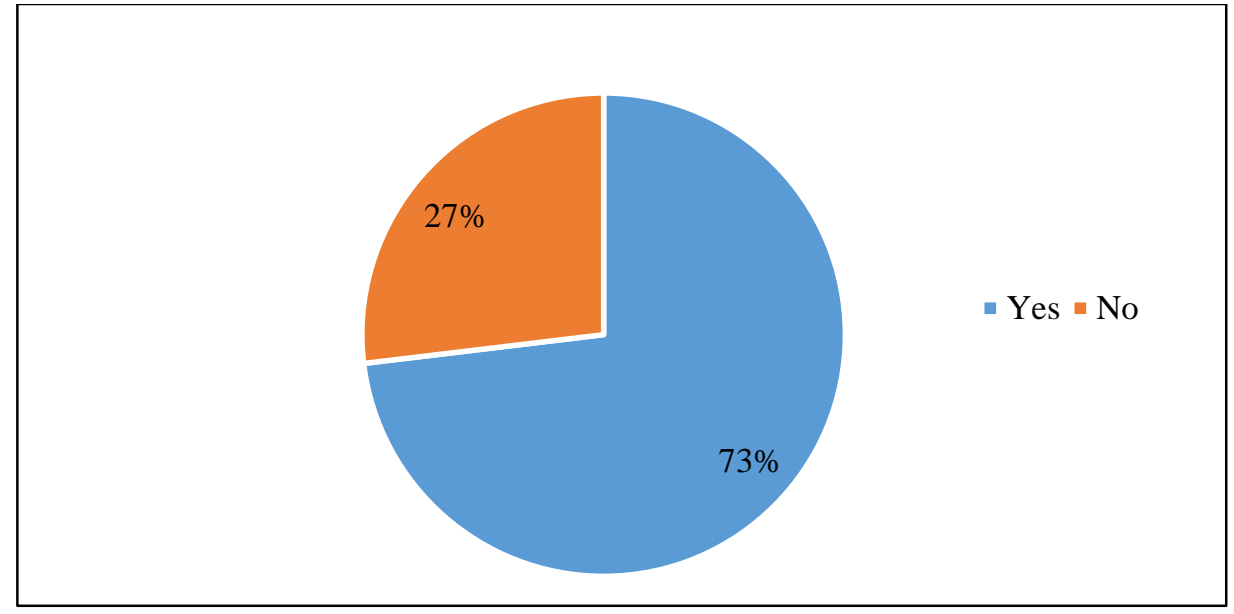

Source: Online voluntary response survey, October 2020

\section{Impact of Covid-19 Lockdown on Socio-Economic Conditions of the Returnee Migrants Workers}

In the previous section, it is evident that majority of the returnee migrant families depend on the remittance, and they have to retune home in a pandemic situation. This section describes immediate impact of Covid-19 lockdown on socio-economic conditions of the returnee migrants' workers in Bangladesh.

\section{Name of returning countries}

As it is illustrated in Figure-3 the largest proportion of the Bangladeshi returnee migrants are from Singapore and Saudi Arabia with 23\% (6 respondents) and 15\% (4 respondents), respectively. Besides, returnee migrants from following these countries UK, Dubai, Malaysia have $12 \%$ respondents. Where returnee migrants from Libya, Oman have 8 percent of respondents and Thailand, Maldives and Spain have only 4 percent of the total respondents.

\section{Figure-3: Name of Returning Countries}

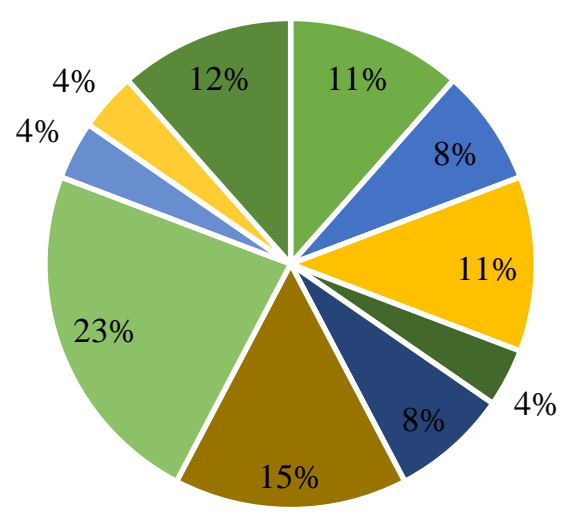

- Dubai

- Libya

- Malaysia

- Maldives

- Oman

- Saudi Arabia

- Singapore

- Spain

$\square$ Thailand

- UK

Source: Online voluntary response survey, October 2020 
Impact of Covid-19 Lockdown on Socio-Economic Conditions of Semi-Skilled Returnee Migrant Workers of Bangladesh

\section{Reasons behind returning home}

As it is shown in Figure-4, majority (54\%) of the Bangladeshi returnee migrants respond that the reason behind returning home is shutting down of their work/ business due to COVID-19 lockdown. Other respondents mentioned that renewing of their visa $(15 \%)$ and job contract renew (15\%) are other reasons to return home. Besides, $8 \%$ and $4 \%$ of the workers response that they return home due to starting self-employed and losing their job in abroad respectively.

\section{Figure-4: Reasons of returning home}

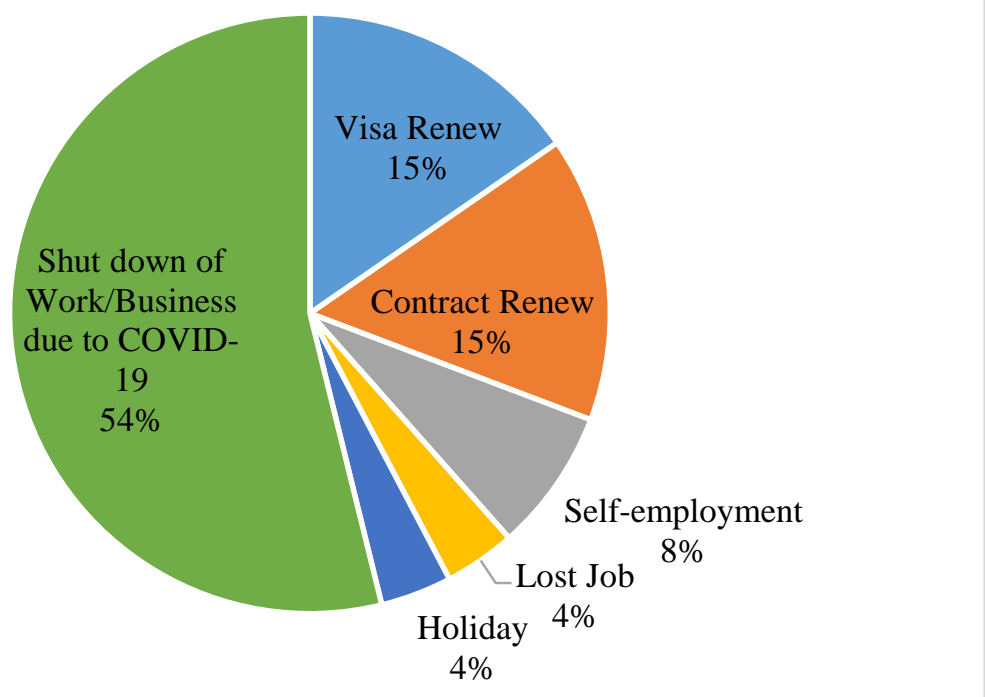

Source: Online voluntary response survey, October 2020

\section{Social and healthcare related challenges}

The returnee workers face various social and healthcare related challenges during lockdown (Figure-5). Among the 26 respondents, $30.8 \%$ of returnee workers mentioned that they faced problems to get health care services and $11.5 \%$ were facing challenges to maintain the quarantine in home country. It is important to note that half of the returnee migrants did not mentioned where they maintained quarantine after returning home. $46 \%$ of them respond that they have maintained quarantine at home and only $4 \%$ of the respondents mentioned that they have maintained quarantine at camp that was arranged by the government. However, $21.35 \%$ of workers were condemned for spreading corona virus by their neighbours after returning home.

Figure-5: Social and healthcare challenges of returnee workers

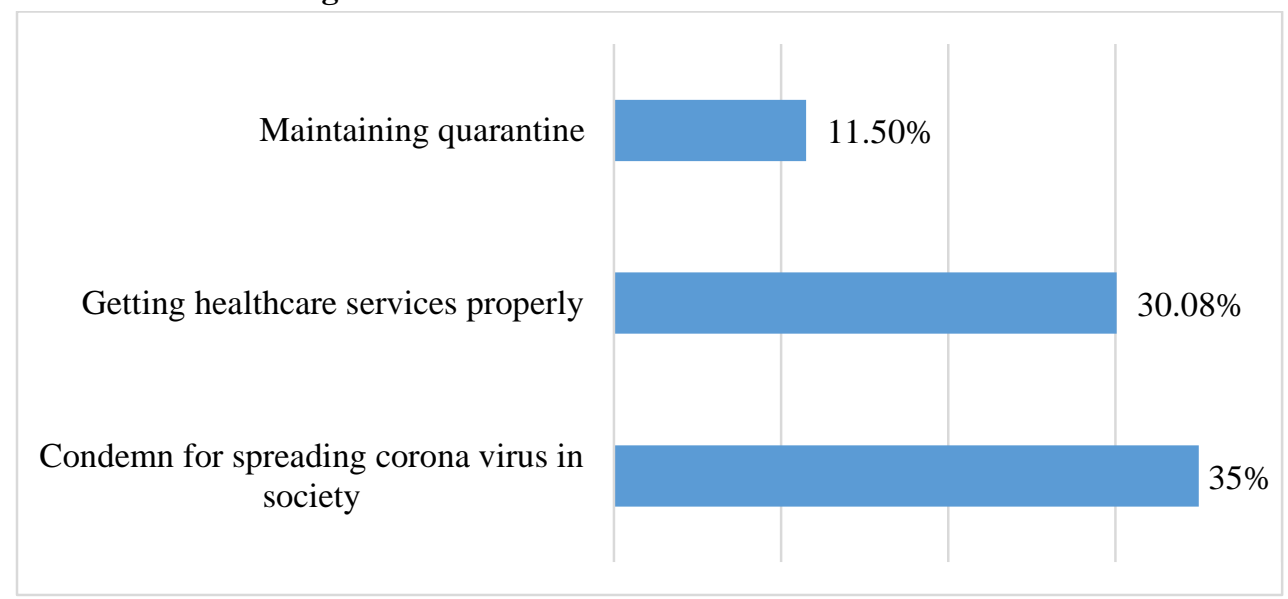

Source: Online voluntary response survey, October 2020

Note: Multiple answer were possible

Income sufficiency and ways of household expenditure

During the lockdown the returnee workers have faced economic challenges for maintaining their daily life and family expenses. According to Figure-6, only $11.5 \%$ of the respondents had income sufficiency during the lockdown and the rest of respondents had 


\section{Impact of Covid-19 Lockdown on Socio-Economic Conditions of Semi-Skilled Returnee Migrant Workers of Bangladesh}

faced economic challenges for maintain household expenditure. Among other respondents, the majority of the workers (69\%) maintained the household consumptions from their savings. Again, 15.5\% returnee workers managed household consumption by borrowing money from others. Rest of the workers (4\%) opine that they sold household valuables to maintain household expenditure during lockdown.

Figure-6: Income sufficiency and ways of household expenditure

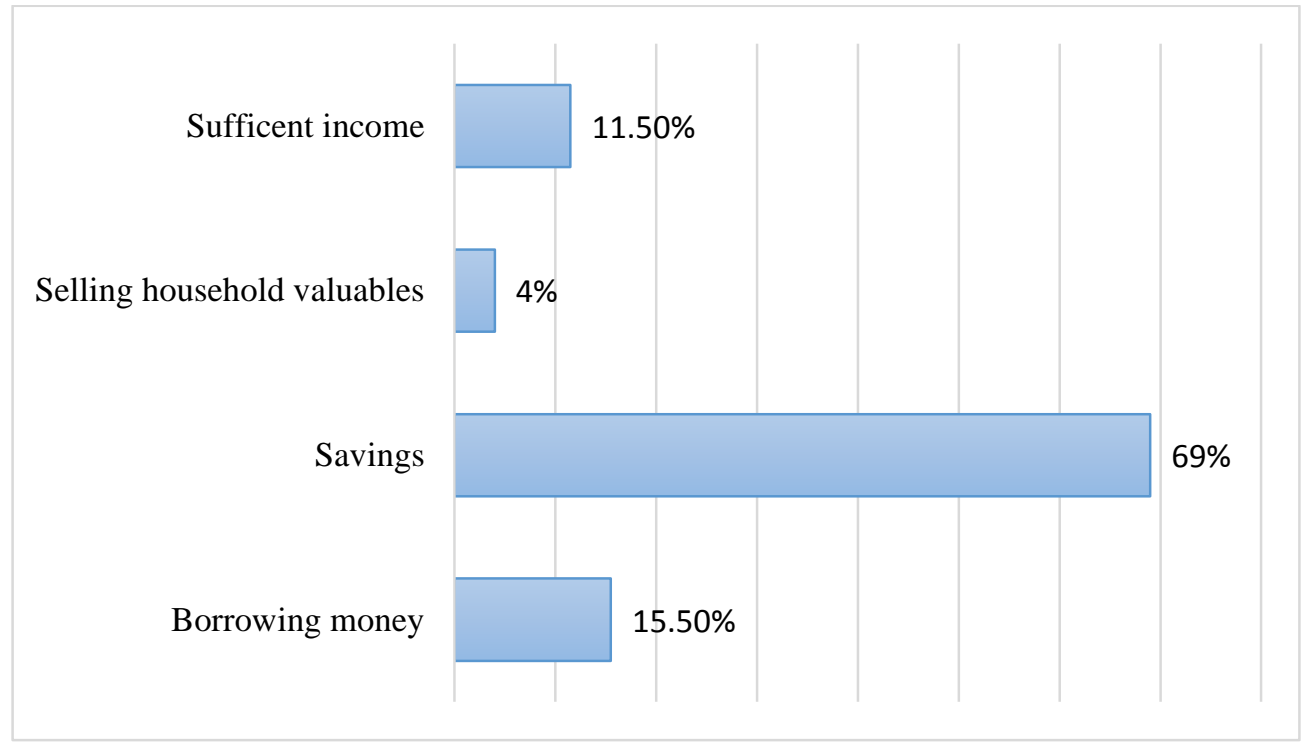

Source: Online voluntary response survey, October 2020

\section{Future plan and problems related to remigration}

After four months of lockdown, out of 26 respondents the 20 returnee workers (77\%) have planned for remigration. $19 \%$ of the returnee migrants did not want to migrate again and $4 \%$ have not decided yet. Among the 20 workers planned for remigration 13 returnee workers $(65 \%)$ are facing problems with the rejoining initiatives, and 7 workers (35\%) have no problems regarding remigration. According to Figure- 7, problems related to returnee migrant workers remigration include financial arrangement (26\%), visa renewing $(31 \%)$, getting plane tickets on time $(26 \%)$, collecting corona negative certificates on time (13\%) and renewing preferred work contracts $(4 \%)$.

\section{Figure-7: Problems of remigration of the returnee workers}

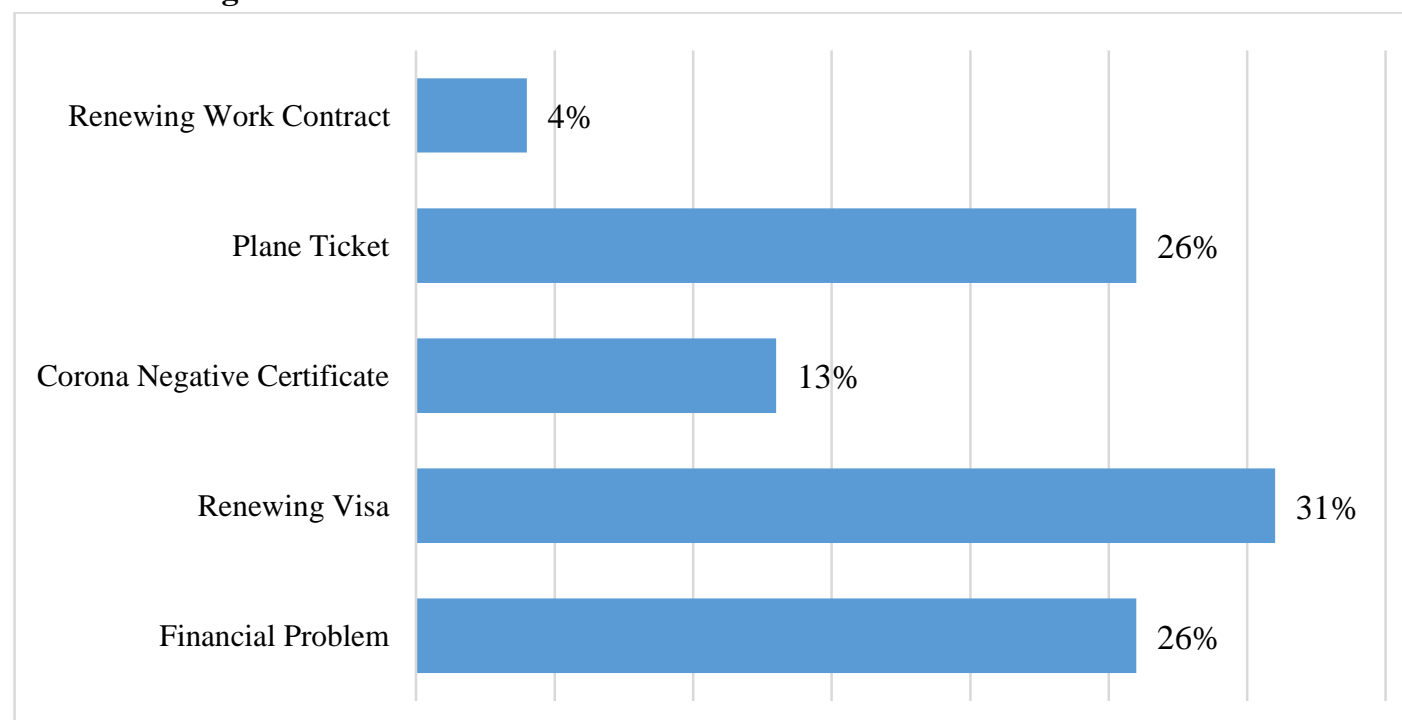

Source: Online voluntary response survey, October 2020

\section{CONCLUSION}

The semi-skilled migrant workers are very important for the socio-economic progress of developing countries like Bangladesh. The main objective of the study was to explore the immediate impact of Covid-19 lockdown on socio-economic conditions of semi- 
skilled returnee migrant workers in Bangladesh. It uses online voluntary response survey tool to collect data from the returnee migrates workers after four month of lockdown. It follows descriptive statistical analysis to present the research result.

The study finds that the majority of the returnee migrant's family members are dependent on the remittance. The workers return home because of the shutting down of their income sources due to a prolong period of lockdown. After returning home many returnee migrants get harassed by their neighbour and have problems in receiving healthcare services and maintain quarantine. Some of the returnee migrant workers condemn for spreading corona virus in society. Most of the returnee workers spend their savings to survive during lockdown.

After four month of lockdown, the returnee migrant workers who think about remigration and re-join their previous job, they face several challenges like financial problem, visa renewing assistance, job contract renewing, unavailability of plane tickets, and getting corona negative certificate on time. The policy makers need to take into account the above mentioned findings to deign future policy for survival of the returnee migrant workers in home country in an emergency situation and their immediate safe re-migration.

\section{REFERENCES}

1) Abdullah, A., \& Hossain, M. (2014). Brain drain: Economic and Social Sufferings for Bangladesh. Asian Journal of Humanity, Art and Literature, 1(1), 9-17.

2) Abrar C R (2020). "Covid-19 And Migrant Workers: Planning the return and reintegration of forced returnees", Retrieved July 8, 2020 from https://www.thedailystar.net/opinion/news/covid-19-and-migrant-workers-planning-the-return-andreintegration-forced-returnees-1926569

3) Ala Uddin (2020). The 'Othering' of returnee migrants in Bangladesh as they are seen as COVID-19 'importers', Retrieved June 22, 2020 From https://www.identitiesjournal.com/covid-19-blog-series/the-othering-of-returnee-migrants-inbangladesh-as-they-are-seen-as-covid-19-importers

4) ILO. (2014). Skilling the workforce: Labour migration and skills recognition and certification in Bangladesh (Dhaka). Retrieved August 1, 2020, from

http://www.skillsforemployment.org/wcmstest4/idcplg?IdcService=GET_FILE\&amp;dID=182170\&amp;dDocName=W CMSTEST4_123648\&amp;allowInterrupt=1.

5) Karim, M.R., Islam, M.T. and Talukder, B., (2020). COVID-19' s impacts on migrant workers from Bangladesh: In search of policy intervention. World Development, Vol. 136, pp: 105-123.

6) Rahman, M. M. (2017). Bangladeshi Migration to Singapore: A Process Oriented Approach, Singapore: Springer Verlag

7) Sarker, M. and Islam, S., (2018). Impacts of international migration on socio-economic development in Bangladesh. European Review of Applied Sociology, 11(16), 27-35.

8) Siddique, A., Selvanathan, E.A., and Selvanathan, S. (2012) Remittances and economic growth: empirical evidence from Bangladesh, India and Sri Lanka. Journal of Development Studies, (48) 1045-1062.

9) Siddiqui, T. (2005). International labour migration from Bangladesh: A decent work perspective. Working Paper No. 66, Geneva: International Labour Office

10) Sorkar, M.N.I. (2020). "COVID-19 Pandemic Profoundly Affects Bangladeshi Workers Abroad with Consequences for Origin Communities". Retrieved August 1, 2020, from: https://www.migrationpolicy.org/article/covid-19-pandemicprofoundly-affects-bangladeshi-workers-abroad-consequences-origin

11) UNDP (United Nations Development Programme), (2020) “Covid-19: an uncertain homecoming for Bangladeshi migrant workers”, Retrieved July 19, 2020 from https://www.bd.undp.org/content/bangladesh/en/home/stories/covid-19-an-uncertain-homecoming-for-bangladeshi-migrant-worker.html 